\title{
Impact of Covid-19 Pandemic on Balance of Payments: Evidence from Developed and Developing Countries
}

\author{
Sohibjamol H. Jumaeva
}

\begin{abstract}
The article is devoted to the consideration of the pandemic impact on the balance of payments of developed and developing countries. In addition, the article presents proposals and recommendations aimed at mitigating the impact of pandemic on the balance of payments in the Republic of Uzbekistan.
\end{abstract}

Index Terms - pandemic, monetary policy, devaluation, exports, imports, balance of goods and services, capital movements, gold and foreign exchange reserves.

\section{INTRODUCTION}

The necessity to finance programs aimed at supporting the economy in response to the crisis of COVID-19 has resulted in the significant increase in external debt in both developed and developing countries. Moreover, if the economic growth rate has dramatically reduced in some countries, then the economy of other countries is challenging negative situation.

Disruptions occurred in global supply chains due to the spread of the COVID-19 pandemic. This, in turn, has made a significant negative impact on the flow of international trade and investments. As a result of the decrease in export revenues, there has been experienced a strong pressure on the exchange rate of national currencies, capital outflow and decline in international reserves due to the foreign exchange intervention of central banks. In particular, in terms of Uzbekistan, appropriate measures are being undertaken to prevent the deepening of the economic crisis caused by the pandemic and to mitigate its consequences. These measures include possible restoration of business entities, assistance to companies that have suffered greatly from the crisis, providing tax and credit holidays, exemptions from rental charges.

Meanwhile, assessing the impact of the pandemic on the country's balance of payments, the use of reasonable policies and levers aimed at mitigating it are of a particular importance and considered to be prior objectives.

\section{LITERATURE REVIEW}

Under the conditions of the pandemic, governments are actively applying various policies and measures to mitigate the consequences of the economic crisis.

In the opinion of M. Guzman, J. Ocampo, and J. Stiglitz markets will be neither efficient nor sustainable without government intervention. Currently resent, almost all countries intervene in the market, the least interference occurs at least through setting interest rates (using monetary policy) [1].

According to the research made by R. Nakatani, the impact of currency devaluation on the economy will be positive in terms of a sharp reduction in prices for the country's basic export goods [2].

From the point of scholars - economists A. Sh. Bekmurodov and N. H. Jumaev, it is not enough to consider the balance of payments as a monetary phenomenon and use only monetary and currency policies' support to regulate it. In this regard, the regulation of the balance of payments should not be limited with the application of monetary and foreign exchange mechanisms. It requires the reasonable use of such combination of policy levers as expansion of high value-added production, implementation of comprehensive measures to improve the business and investment climate in the country with the aim of attracting foreign investments. [3].

Moreover, some researchers suppose that in overcoming the balance of payments crisis, such factors as monetary policy transmission channels, liquidity in the banking sector, structural liquidity deficit, financial system structure, financial markets development, as well as financial stability risks should be taken into account [4].

\section{ANALYSIS AND RESULTS DISCUSSION}

It is a well-known fact that the economic consequences of the pandemic have been equally negative for developed and developing countries. To assess the negative impact of the pandemic on the economies of countries, it would be relevant to analyze and evaluate changes in their balance of payments.

In the USA the trade balance deficit has expanded due to the global pandemic, while exports have reached the lowest indicator during 10-year period of time. In the first quarter of 2020, the current account deficit constituted 104.2 billion USD or $1.9 \%$ of the national GDP. In a sense, the COVID19 pandemic has contributed to this deficit emergence. In particular, business representatives had to operate in limited conditions and tourists were not allowed to cross the border. 
TABLE I: COMPOSITION OF THE BALANCE OF GOODS AND SERVICES OF THE USA*

\begin{tabular}{|c|c|c|c|c|c|c|c|}
\hline & \multirow{2}{*}{2018} & \multicolumn{4}{|c|}{2019} & \multirow[t]{2}{*}{$\begin{array}{c}\text { quarter I of } \\
2020 \\
\end{array}$} & \multirow[t]{2}{*}{$\begin{array}{l}\text { Change of quarter I of } 2020 \text { in } \\
\text { relation to quarter IV of } 2020\end{array}$} \\
\hline & & quarter I & quarter II & quarter III & quarter IV & & \\
\hline $\begin{array}{l}\text { Export of } \\
\text { goods } \\
\text { and } \\
\text { services }\end{array}$ & 2539,3 & 947,7 & 953,9 & 954,4 & 949,8 & 902,3 & $-47,5$ \\
\hline $\begin{array}{l}\text { Import of } \\
\text { goods } \\
\text { and } \\
\text { services }\end{array}$ & 3119,3 & 779,4 & 783,6 & 779,8 & 762,2 & 731,4 & $-30,8$ \\
\hline
\end{tabular}

* Developed by the author on the basis of the data of the Bureau of Economic Analysis of the USA

\section{DISCUSSION}

In particular, the situation given below has been observed in the United States of America in quarter I of 2020 by imported items. The following indicators have decreased:

- imports of fuel and energy products - by 5.1 billion USD;

- imports of non-automotive capital goods - by 6.3 billion USD;

- imports of cars, spare parts and engines - by 1.9 billion USD;

- imports of consumer goods (excluding food and motor vehicles) - by 6.7 billion USD.

On the contrary, during this period, non-monetary gold imports have increased by 1.5 billion USD.

In terms of exports the following changes have occurred in quarter II of 2020 by exported items. The following indicators have reduced:

- exports of non-automotive capital goods - by 3.7 billion USD;

USD;

- exports of consumer goods (excluding food and motor vehicles) - by 2,8 billion USD.

However, during this period, exports of food and beverages, industrial raw materials and supplies have increased by 636 million USD and 1043 million USD respectively.

During the analyzed period, the US exports of services have decreased by 1.7 billion USD. In particular, transport services have reduced by 2.4 billion USD; travel expenses (for all purposes, including education) - by 9.2 billion USD; financial services - by 798 million USD.

Similarly, in the first quarter of 2020 imports of services in the United States have decreased by 12.2 billion USD. In particular, transport services have reduced by 3.9 billion USD, and travel expenses (for all purposes, including education) - have reduced by 8.9 billion USD.

It should be noted that the USA has implemented a number of measures to mitigate the negative effects of the pandemic in the United States. The US Federal Reserve System (FRT) has set a federal fund rate target that affects interest rates in the money market in the range of $0-0.25 \%$. In this way, the FRS intends to reduce the rates of shortterm and long-term loans extended by banks to businesses and the population, i.e. to reduce the cost of financial resources in the crisis period.

Moreover, the FRS tried to purchase securities under the quantitative easing $(\mathrm{QE})$ policy, as in within the framework of the 2009 global financial crisis, and thereby raising money supply. In particular, on March 15, 2020 the FRS announced the purchase of state-guaranteed mortgage securities in the amount of 200 billion USD and the US Treasury bills in the amount of 500 billion USD in terms of the initial purchases volume. As a result of quantitative easing measures, in the period from mid-March to mid-June 2020, the FRS securities portfolio has increased from 3.9 trillion. to 6.1 trillion USD.

In addition, the FRS has introduced the practice of direct lending to 24 financial institutions, which are considered to be the main dealers, at low rates $(0.25 \%)$ for up to 90 days. The aim for this measure was to ensure the functioning of credit markets within the crisis period.

The FRS has simultaneously applied traditional monetary policy instruments to mitigate the impact of the pandemic on the US economy. In particular, these are REPO operations, financing through the discount window, etc.

The consequences of the pandemic in the Russian Federation and its impact on the balance of payments on the example of developing countries can be considered as evidence of the Russian federation.

In the first half of 2020, the current account surplus in the Russian Federation has constituted 22.3 billion USD [5]. For comparison: in the corresponding period of the last year, the current account surplus amounted to 43.4 billion USD. Significant decline in surplus has occurred due to the decline in exports which have been caused by unfavorable conditions in the fuel and energy market. In addition, there has been a decrease in the volume of imports of goods during the reporting period. However, imports of goods declined at a lower rate than its exports.

In the first half of 2020, the balance of private sector financial transactions in the Russian Federation constituted 28.9 USD. This figure is 5.6 billion USD more than in the same period last year.

In addition, international reserves of Russia have reduced by 7.9 billion USD. There are two reasons for this: 1) operations related to the settlement of sovereign debts; 2) sale of foreign exchange by the Central Bank of Russia.

However, in the second quarter of 2020, the negative impact of the global pandemic on the balance of payments has increased. Revenues from oil and gas exports have declined sharply as well. This, in turn, has occurred because of the decline in oil production in Russia under the OPEC + agreements and falling prices due to low demand for oil.

At the end of quarter 1 of 2020, the current account balance of the Republic of Uzbekistan was in deficit and amounted to 812.18 USD (see Table 2). 2020 However, it would not be correct to refer the current account deficit only 
to the global pandemic. This is due to the fact that in the same period last year there was a deficit of 1049.9 million USD. In general, the current account in our country has been in deficit (except for quarter 3 of 2019) for the last two years".

TABLE 2: COMPOSITION OF THE BALANCE OF PAYMENTS OF THE REPUBLIC OF UZBEKISTAN IN MILLION USD
\begin{tabular}{|c|c|c|c|c|c|c|}
\hline № & $\begin{array}{c}\text { Balance of payments } \\
\text { sections }\end{array}$ & $\begin{array}{c}\text { quarter 1 } \\
\text { of } 2016\end{array}$ & $\begin{array}{c}\text { quarter 1 of } \\
2017\end{array}$ & $\begin{array}{c}\text { quarter 1 } \\
\text { of } 2018\end{array}$ & $\begin{array}{c}\text { quarter 1 } \\
\text { of } 2019\end{array}$ & $\begin{array}{c}\text { quarter 1 of } \\
2020\end{array}$ \\
\hline I & $\begin{array}{c}\text { Balance of current } \\
\text { operations account }\end{array}$ & $-375,25$ & $-280,87$ & $-225,65$ & $-1049,90$ & $-812,18$ \\
\hline 1.1 & Balance of goods & $-624,51$ & $-899,70$ & $-770,86$ & $-1696,74$ & $-1578,99$ \\
\hline 1.2. & $\begin{array}{c}\text { Remainder of the } \\
\text { balance of goods and } \\
\text { services }\end{array}$ & $-940,43$ & $-1242,19$ & $-1340,70$ & $-2250,78$ & $-2038,04$ \\
\hline II & $\begin{array}{c}\text { Balance of capital } \\
\text { operations account }\end{array}$ & $-372,78$ & $-272,98$ & $-197,53$ & $-914,8$ & $-812,03$ \\
\hline II & Financial account & $-2,57$ & 40,93 & $-412,19$ & $-2206,14$ & $-719,71$ \\
\hline
\end{tabular}

It should be noted that imports of goods in the country in all quarters of the fiscal year exceeded its exports over the past two years. This was also the case with the export and import of services.

\section{CONCLUSION AND PROPOSALS}

The COVID-19 pandemic has negatively affected the global supply chains and economic integration achieved in the world economy. Its consequences have been evident in the slowdown in the economies of developed and developing countries, the decline in foreign trade and investments. This is confirmed by the balance of payments of these countries.

In terms of a pandemic, declining export earnings, covering the trade deficit could lead to the depletion of foreign reserves. On the other hand, as public external debt increases, more reserves are required to maintain international liquidity and solvency.

It is necessary to prevent a sharp rise in the real exchange rate of the UZS against the currencies of major trading partners of Uzbekistan, and with this aim to allow free formation and depreciation of the UZS exchange rate. In our opinion, the effect of the UZS devaluation on the national economy is reflected in the following factors: first, it results in the reduction in expenditures in the national currency on the balance sheets of foreign companies; second, the volume of tax payments to the state budget will rise due to the increase in profits of companies; third, it promotes the export of goods; fourth, the volume of gold and foreign exchange reserves of the Central Bank will be maintained; fifth, as the population shifts from imported goods to domestic goods as a result of rising import prices, domestic industry will develop.

To support domestic producers, the Central Bank's policy should focus on reducing the cost of financial resources and raising money supply through various measures aimed at raising liquidity (REPO, credit auctions, open market operations).

\section{REFERENCES}

[1] Guzman M., Ocampo J.A., Stiglitz J.E. (2018) Real exchange rate policies for economic development// World Development 110 (2018) 51-62.

[2] Ryota Nakatani (2018) Adjustment to negative price shocks by a commodity exporting economy: Does exchange rate flexibility resolve a balance of payments crisis? //Journal of Asian Economics 57 (2018) 13-35.

[3] Bekmurodov A. Sh., Jumaev N. Kh. Conceptual aspects of balance of payments regulation in terms of the monetary policy liberalization//electronic journal "Uzbridge”. № I. 2019. P.3-14.

[4] Sinyakov Andrey, Yudaeva Ksenia (2016). Central bank policy under significant balance-of-payment shocks and structural shifts // Russian Journal of Economics 2 (2016) 246-278

[5] Balance of payments (2020). Balance of payments of Russia. №1 (3). I quarter of 2020. 